\title{
The Recruitment of the Endangered Fan Mussel Pinna nobilis (Linnaeus, 1758) on the Ropes of a Mediterranean Mussel Long Line Farm
}

Authors: Theodorou, John A., James, Ross, Tzovenis, Ioannis, and Hellio, Claire

Source: Journal of Shellfish Research, 34(2) : 409-414

Published By: National Shellfisheries Association

URL: https://doi.org/10.2983/035.034.0224

BioOne Complete (complete.BioOne.org) is a full-text database of 200 subscribed and open-access titles in the biological, ecological, and environmental sciences published by nonprofit societies, associations, museums, institutions, and presses.

Your use of this PDF, the BioOne Complete website, and all posted and associated content indicates your acceptance of BioOne's Terms of Use, available at www.bioone.org/terms-of-use.

Usage of BioOne Complete content is strictly limited to personal, educational, and non - commercial use. Commercial inquiries or rights and permissions requests should be directed to the individual publisher as copyright holder.

BioOne sees sustainable scholarly publishing as an inherently collaborative enterprise connecting authors, nonprofit publishers, academic institutions, research libraries, and research funders in the common goal of maximizing access to critical research. 


\title{
THE RECRUITMENT OF THE ENDANGERED FAN MUSSEL PINNA NOBILIS (LINNAEUS, 1758) ON THE ROPES OF A MEDITERRANEAN MUSSEL LONG LINE FARM
}

\author{
JOHN A. THEODOROU, ${ }^{1}{ }^{*}$ ROSS JAMES, ${ }^{2}$ IOANNIS TZOVENIS ${ }^{3}$ AND CLAIRE HELLIO $^{4}$ \\ ${ }^{1}$ Department of Fisheries and Aquaculture Technology, Technological Educational Institution (TEI) of \\ Western Greece, Nea Ktiria, GR 30200 Mesolonghi, Greece; ${ }^{2}$ School of Biological Sciences, King Henry \\ Building, University of Portsmouth, Portsmouth PO1 2DY, United Kingdom; ${ }^{3}$ Laboratory of Ecology and \\ Systematics, Biology Department, University of Athens, Panepistimioupolis, Zografou 15784, Greece; \\ ${ }^{4}$ Laboratoire des Sciences de l'Environnement Marin-lemar umr 6539, Université de Bretagne Occiden- \\ tale, Brest, France
}

\begin{abstract}
The fan mussel Pinna nobilis (Linnaeus, 1758) is an endangered bivalve species and is endemic to the Mediterranean Sea. Juvenile animals have been found growing on mussels Mytilus galloprovincialis (Lamarck, 1819) long line aquaculture bounces and ropes within the Maliakos Gulf (Aegean Sea). Animals were sampled from the harvested mussel lines. The results show twelve juvenile $P$. nobilis per ton of harvested M. galloprovincialis.
\end{abstract}

KEY WORDS: fan mussel, Pinna nobilis, recruitment, biofouling, Mediterranean mussel aquaculture, Mytilus galloprovincialis, Maliakos Gulf, Aegean Sea

\section{INTRODUCTION}

The largest endemic Pteriomorphian bivalve in the Mediterranean Sea is Pinna nobilis (Linnaeus, 1758); growing up to $120 \mathrm{~cm}$ long (Zavodnik et al. 1991). Populations of P. nobilis have declined significantly within the last 30 y (Vicente \& Moreteau 1991) because of consumption for food or ornaments and collaterally from trawling and boat anchoring (GalinouMitsoudi et al. 2006, Centoducati et al. 2007, Katsanevakis 2006, 2007, Katsanevakis et al. 2011, Katsanevakis \& ThessalouLegaki 2009, Vafidis et al. 2014). This species is protected by the Mediterranean Specially Protected Areas protocol (95/96 SPA ANNEX II) and under European legislation (92/43 EEC). Although there is intensive research regarding the population ecology and the species distribution around Mediterranean (Zavodnik 1967, Zavodnik et al. 1991, de Gaulejac \& Vicente 1990, Butler et al. 1993, García-March \& Ferrer 1995, Richardson et al. 1999, Siletic \& Peharda 2003, Galinou-Mitsoudi et al. 2006, Centoducati et al. 2007, García-March et al. 2002, García-March \& Vicente 2006, García-March et al. 2007a, b, Rabaoui et al. 2008, 2009, 2010, Katsares et al. 2008, Katsanevakis \& Thessalou-Legaki 2009, Coppa et al. 2010, 2013, Vafidis et al. 2014), there is limited knowledge about zootechnical aspects of the animal such as feeding behavior (Cabanellas-Reboredo et al. 2009a, Davenport et al. 2011, Najdek et al. 2013, Trigos et al. 2014), reproduction (de Gaulejac et al. 1995a, b, Richardson et al. 2004), and the recruitment (Peharda \& Vilibic 2008, Cabanellas-Reboredo et al. 2009b, Acarli et al. 2011a, Soria et al. 2014).

This study on the recruitment of Pinna nobilis on Mytilus galloprovincialis long line farming ropes within the Maliakos Gulf in Greece (Fig. 1) was undertaken with the aim of bringing to light empirical observations regarding the recruitment process of $P$. nobilis for the future protection of the species and possibilities for aquaculture.

The role of bivalve shellfish farming installations on the natural recruitment and restocking of wild endangered species/

*Corresponding author. E-mail: jtheo@teimes.gr DOI: $10.2983 / 035.034 .0224$ biofoulants, such as the fan mussel in the present case, is also discussed.

\section{MATERIALS AND METHODS}

\section{Study Area}

The mussel farm installation is a single floating long line suspended culture system (Theodorou et al. 2015a) located in the southern part of the Maliakos Gulf $\left(38^{\circ} 51^{\prime} 39.82^{\prime \prime} \mathrm{N}, 22^{\circ}\right.$ $41^{\prime} 45.54^{\prime \prime}$ E) in Central East Continental, Greece (Fig. 1). Maliakos is a natural semienclosed embayment in Central West Aegean Sea (belonging to the EU Natura 2000 Network) and harbors populations of various commercial exploitable bivalves including native oysters Ostrea edulis (Linnaeus, 1758), warty venus Venus verrucosa (Linnaeus, 1758), and Mediterranean mussel Mytilus galloprovincialis (Lamarck, 1819). During the last two decades, 10 long line farms were established in an effort to provide seafood in a sustainable way, giving an annual total mussel production of about 1,500-1,700 tonnes per year. Details about the environmental status and the local conditions of the mussel farm site used in the present study are given by Dimitriou et al. (2015) and Rodrigues et al. (2015).

\section{Biological Material}

The fan mussel Pinna nobilis (Linnaeus, 1758) population is an endemic species in Maliakos, with a well-established population, despite being that it is as an endangered species. This indicates the efficacy of protection from the human activities pressures and the "good environmental health" status of the area (James et al. 2010, Tagalis \& Theodorou 2013, Theodorou et al. 2015b).

\section{Experimental Method}

\section{Sampling}

The specimens of Pinna nobilis were measured on board immediately, after the Mytilus galloprovincialis long lines were 


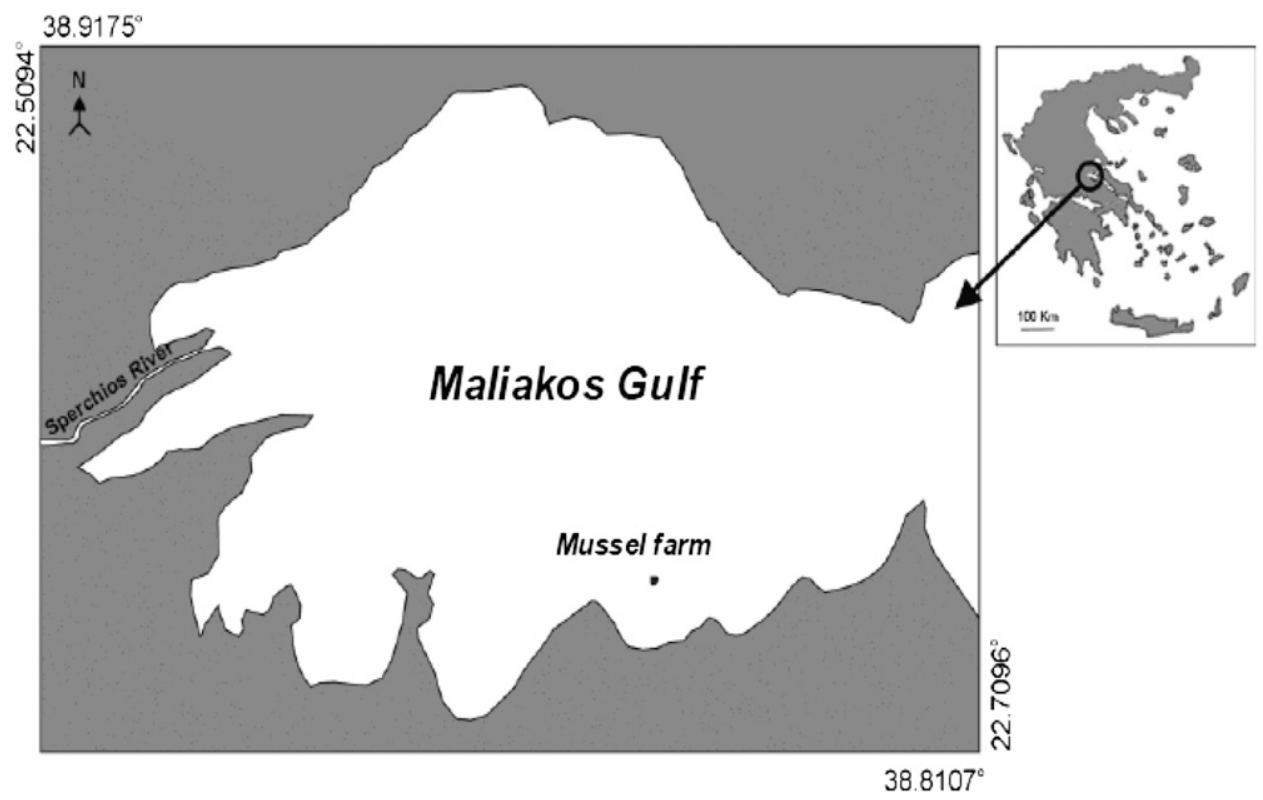

Figure 1. Mussel farm site in Maliakos Gulf (Aegean Sea, East Central Greece) where Pinna nobilis individuals were collected during the mussel harvesting process.

harvested during the summer-early autumn of 2009 (Fig. 2A, B). Measurements were taken using a Vernier Caliper with a resolution of $0.02 \mathrm{~mm}$ : the length $(\mathrm{cm})$ and maximum width $(\mathrm{cm})$ were recorded according to the guidelines of García-March et al. (2002) for the Pinna in vivo measurements. Shells were also rated as to whether they had been noticeably damaged in the process of harvesting and whether their regular morphology is slightly modified (after the typology demonstrated in Garcia-March \& Vicente 2006) because of the space restrictions caused by close proximity to $M$. galloprovincialis. The samples were taken from a working mussel farming site and were harvested by chance from $100 \mathrm{~m}$ stretches of long line that had been developing for over $1 \mathrm{y}$. Samples were collected from three harvests of $\sim 2$ tonnes each of $M$. galloprovincialis (unsorted).

\section{Data Analysis}

A Microsoft Excel spreadsheet was drawn taking into the account the morphometric data of the harvested animals. Statistical comparisons between length and width were tested
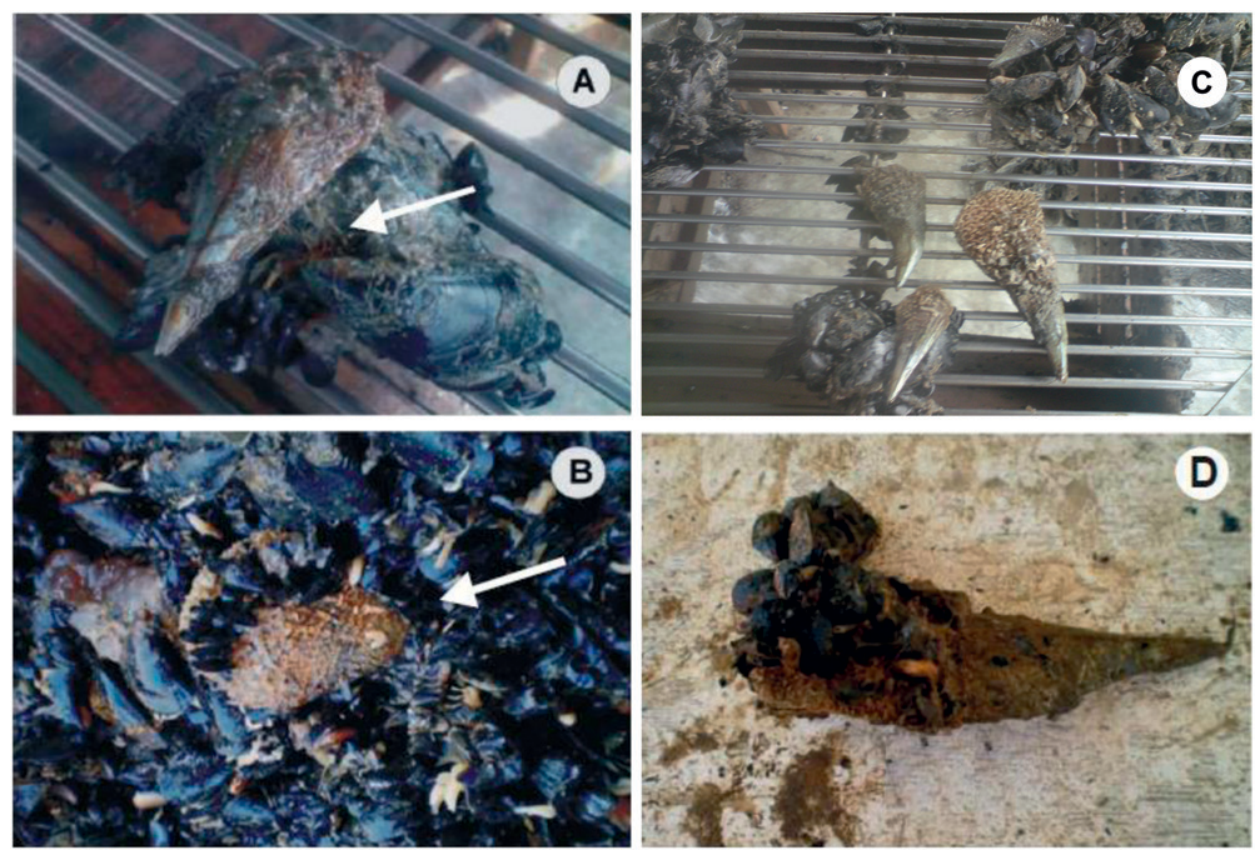

Figure 2. (A, B) Juveniles of Pinna nobilis with Mytilus galloprovincialis attached. (C, D) Various forms of P. nobilis juveniles: C-left, combed; C-right, straight wide; D, straight narrow. 
through the application of one-way analysis of variance (ANOVA) using MiniTab statistical software.

\section{RESULTS}

A total of 72 animals were collected from the sample site. The three main typologies presented by García-March and Vicente (2006) were distinguished, in the harvested Pinna nobilis samples: (1) combed (Fig. 2C, left); (2) straight and wide (Fig. 2C, right); (3) straight and narrow (Fig. 2D).

The smallest individual measured $2.85 \mathrm{~cm}$ length and $0.94 \mathrm{~cm}$ width, the largest measured $19.36 \mathrm{~cm}$ length and $10.19 \mathrm{~cm}$ width; the average size being $13.45 \pm 3.16 \mathrm{~cm}$ (length) and $6.21 \mathrm{~cm} \pm 1.82$ (width). ANOVA comparison between the length $(\mathrm{cm})$ and width (cm) gave a result of $F=5.64$ and $P<0.05$, showing a significance between the length and the width if $\mathrm{H}_{0}=$ no significance and where the $\alpha$ level is 0.05 (Fig. 3). Broken/malformed shells were included in the analysis.

\section{DISCUSSION}

In our samples, we found a shell shape variation among Pinna animals from the mussel socks (Fig. 2 C, D). This is not suprising, as it is also demonstrated in earlier observations by García-March and Vicente (2006), for individuals originated from the same population and from the same vathymetric range. During the life cycle of Pinna nobilis the shell formation shows a diverse morphological plasticity among animals of the same live stage (juveniles or adults) as well as in-between the juvenile and adult stage of the same individuals. In the juvenile stage, this may be related with the phenomenon of ecomorphosis as a result of the animal-substrate habits adaptation (Combelles et al. 1986).

The animals found within the examined mussel farm installation, are of special significance, as this shows that the natural propagation of Pinna nobilis is possible. Seventy-two animals of less than one-year old $(<25 \mathrm{~cm}$ length, Richardson et al. 1999) were found over three separate harvestings of Mytilus galloprovincialis of around 2 tonnes per harvest, equating to around twelve juvenile $P$. nobilis per tonne of Mediterranean mussel. Whereas this figure is low, this species was untargeted and as such was by-catch from the main aquaculture industry. Aquaculture of $M$. galloprovincialis has a set timeline which is as follows (Fig. 4): May-July spat collectors obtain spats which are then put into small hanging nets; once large enough, between August and October, the spat are then resuspended in larger nets at least at once prior to start harvesting early summer (Theodorou et al. 2011, 2014). The significant date is the second renetting of the spats as it has been determined that early spat recruitment of $P$. nobilis takes place within the last week of August and the first week of September and can also be collected using a range of existing bivalve spat collection techniques (Cabanellas-Reboredo et al. 2009b). This recruitment takes place as the second and may be final renetting of $M$. galloprovincialis as this process allows a stable settlement area for spat $P$. nobilis. The fact that there is a large community of bivalve aquaculture in this area may limit the ability of the fan shell to attach to the long line, and once attached, they may be outcompeted for the limited space on the lines themselves. This interesting outcome does give a glimpse into the prospect of aquaculture of this species, presently under investigation worldwide (Beer \& Southgate 2006, Leal-Soto et al. 2011, Mendo et al. 2011), in the future with existing aquaculture facilities and equipment such as on trays/cages (Acarli et al. 2011b, Kozul et al. 2013).

Bivalve shellfish farm installations attract wild organisms (Adams et al. 2011, Fitridge et al. 2012, Sievers et al. 2014) that in most cases are treated as biofoulants. Despite being an endangered species, Pinna nobilis are handled like the rest of

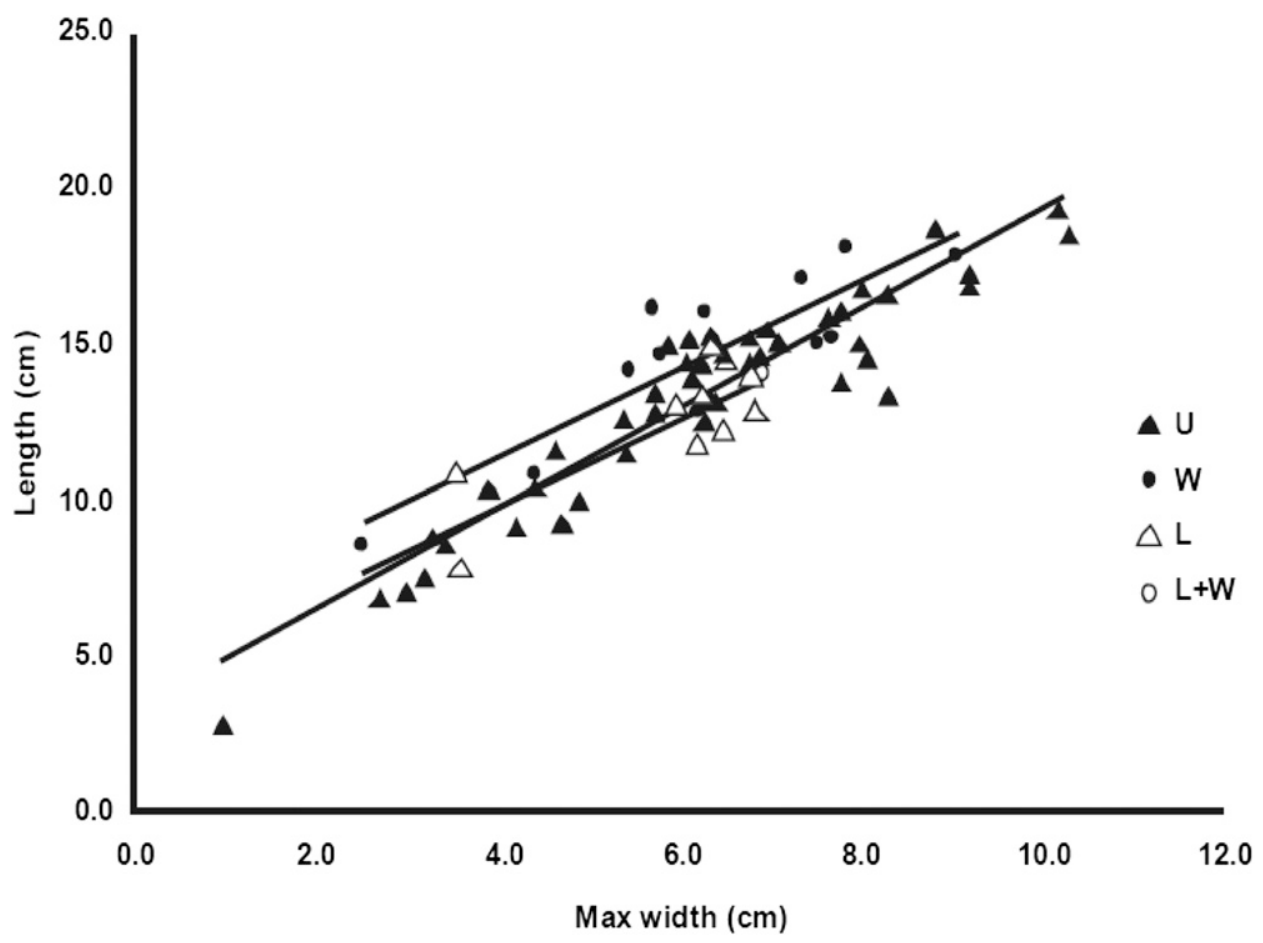

Figure 3. Size of animals found with groups and regression lines. U, unbroken; L, broken length wise; W, broken width wise. 


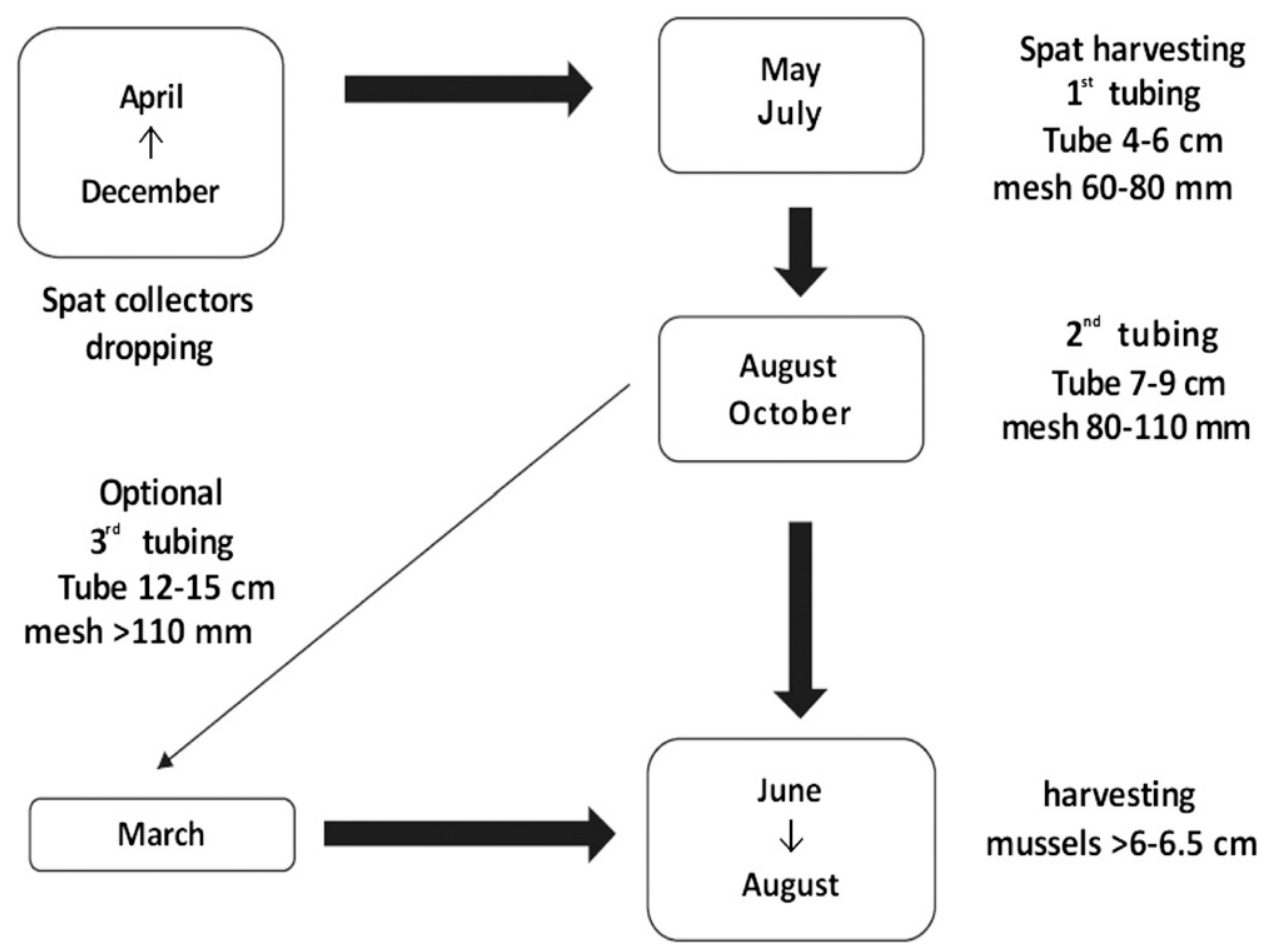

Figure 4. A generalized production model of the Mediterranean mussel farming in Greece (from Theodorou et al. 2011).

the animal by-products of mussel production. Producers usually treat these animals as a biofouling organism without paying attention to the species. As there is not yet any legislation or directives to provide practical guidelines, questions such as who owns the recruited organisms or what must a responsible mussel farmer do, have to be answered. Indeed, guidelines for good environmental practice based on the biology of the species should be available and communicated to shellfish farmers. In addition, more knowledge about the "recreational aquaculture" of the endangered species is needed. The promotion of mussel farmers to the public as "environmental recreation angels" may inspire the farmers to act as "godfathers" of the endangered species, providing, parallel to their own production process, the $P$. nobilis protection and enhancement by providing animals to restock the wild population. An alternative opportunity, coculture, which may add another product and provide supplementary income to the farmers, needs to be investigated in conjunction with the restocking. This practice has been promoted in Europe for another capture-based farmed endangered species, the European eel Anguilla anguilla (Linnaeus, 1758), where the harvesters/producers use part of their animal stock for natural restocking purposes (Jacoby \& Gollock 2014). Similar effort but in a total different case recently demonstrated by Navedo et al. (2014) where the shrimp farm installations in Mexico, under an appropriate management support the conservation efforts of nearctic shorebirds by providing short term but absolute necessary complementary foraging areas. The combination of aquaculture with conservation of wildlife may be is a current research trend in the industry that could be expressed in various forms and species depending on the local ecosystems specifications and requirements. The social acceptance of these practices also could mitigate the negative pressures for environmental impacts of the activity by the rest of the stakeholders.

\section{ACKNOWLEDGMENTS}

This study was carried out with the support of the shellfish farming company Calypso Seafood-Aqua-Consulting Ltd, providing technical assistance for the field surveys and the EU Erasmus Mobility Fund for the student placement of Ross James in Greece.

\section{LITERATURE CITED}

Acarli, S., A. Lök \& D. Acarli. 2011a. Preliminary spat settlement of fan mussel Pinna nobilis Linnaeus 1758 on a mesh bag collector in Karantina Island (Eastern Aegean Sea, Turkey). Fres. Env. Bull. 20:2501-2507.

Acarli, S., A. Lök \& S. Yigitkurt. 2011b. Culture of fan mussel (Pinna nobilis, Linnaeus 1758) in relation to size on suspended culture system in Izmir Bay, Aegean Sea, Turkey. Kafkas Univ. Vet. Fak. Der. 17:995-1002.

Adams, C. M., S. E. Shumway, R. B. Whitlatch \& T. Getchis. 2011. Biofouling in marine molluscan shellfish aquaculture: a survey assessing the business and economic implications of mitigation. $J$. World Aquacult. Soc. 42:242-252.

Beer, C. \& P. C. Southgate. 2006. Spat collection, growth and meat yield of Pinna bicolour (Gmelin) in suspended culture in northern Australia. Aquaculture 258:424-429.

Butler, A., N. Vicente \& B. de Gaulejac. 1993. Ecology of the pterioid bivalves Pinna bicolor Gmelin and Pinna nobilis L. Mar. Life (Marseille) 3:37-45.

Cabanellas-Reboredo, M., S. Deudero \& A. Blanco. 2009a. Stableisotope signatures $(\mathrm{d} 13 \mathrm{C}$ and $\mathrm{d} 15 \mathrm{~N})$ of different tissues of Pinna 
nobilis Linnaeus 1758 (Bivalvia): isotopic variations among tissues and between seasons. J. Molluscan Stud. 75:343-349.

Cabanellas-Reboredo, M., S. Deudero, J. Alós, J. M. Valencia, D. March, I. E Hendriks \& E. Álvarez. 2009b. Recruitment of Pinna nobilis (Mollusca: Bivalvia) on artificial structures. Mar. Biodiversity Rec. 2:126.

Centoducati, G., E. Tarsitano, A. Bottalico, M. Marvulli, O. R. Lai \& G. Crescenzo. 2007. Monitoring of the endangered Pinna nobilis Linnaeus, 1758 in the mar grande of taranto (Ionian Sea, Italy). Environ. Monit. Assess. 131:339-347.

Combelles, S., J. C. Moreteau \& N. Vicente. 1986. Contribution a la connaissance de l'ecologie de Pinna nobilis L. (Mollusque eulamelibranche). Sci. Rep. Port-Cros. Nat. Park. 12:29-43.

Coppa, S., I. Guala, G. A. de Lucia, G. Massaro \& M. Bressan. 2010. Density and distribution patterns of the endangered species Pinna nobilis within a Posidonia oceanica meadow in the Gulf of Oristano (Italy). J. Mar. Biol. Ass. U.K. 90:885-894.

Coppa, S., G. A. de Lucia, P. Magni, P. Domenici, F. Antognarelli, A. Satta \& A. Cuco. 2013. The effect of hydrodynamics on shell orientation and population density of Pinna nobilis in the Gulf of Oristano (Sardinia, Italy). J. Sea Res. 76:201-210.

Davenport, J., D. Ezgeta-Balic, M. Peharda, S. Skejic, Z. NincevicGladan \& S. Matijevic. 2011. Size-differential feeding in Pinna nobilis L. (Mollusca: Bivalvia): exploitation of detritus, phytoplankton and zooplankton. Estuar. Coast. Shelf Sci. 92:246-254.

de Gaulejac, B. \& N. Vicente. 1990. Ecologie de Pinna nobilis (L.) mollusque bivalve sur les cotes de Corse. Essais de transplantation et experiences en milieu de Corse. Essais de transplantation et experiences en milieu controle. Haliotis 20:83-100.

de Gaulejac, B., M. Henry \& N. Vicente. 1995a. An ultrastructural study of gametogenesis of the marine bivalve Pinna nobilis (Linnaeus, 1758). I. Oogenesis. J. Molluscan Stud. 61:375-392.

de Gaulejac, B., M. Henry \& N. Vicente. 1995b. An ultra-structural study of gametogenesis of the marine bivalve Pinna nobilis (Linnaeus, 1758). II. Spermatogenesis. J. Molluscan Stud. 61:393-403.

Dimitriou, P. D., I. Karakassis, P. Pitta, T. M. Tsagaraki, E. T. Apostolaki, I. Magiopoulos, N. Nikolioudakis, S. Diliberto, J. A. Theodorou, I. Tzovenis, I. Kagalou, P. Beza \& M. Tsapakis. 2015. Effects of mussel farming on quality indicators of the marine environment: good benthic below poor pelagic ecological status. Mar. Pollut. Bull. (accepted).

Fitridge, I., T. Dempster, J. Guenther \& R. de Nys. 2012. The impact and control of biofouling in marine aquaculture: a review. Biofouling. 28:649-669.

Galinou-Mitsoudi, S., G. Vlahavas \& O. Papoutsi. 2006. Population study of the protected bivalve Pinna nobilis (Linnaeus, 1758) in Thermaikos Gulf (North Aegean Sea). J. Biol. Res 5:47-53.

García-March, J. R. \& J. F. Ferrer. 1995. Biometría de Pinna nobilis L., 1758: una revisíon de la ecuacion de De Gaulejac Y Vicente (1990). Bol. Inst. Esp. Oceanogr. 11:175-181.

García-March, J. R., A. M. Carcía-Carrascosa \& A. L. Pena. 2002. In situ measurement of Pinna nobilis shells for age and growth studies: a new measurement of device. Mar. Ecol. (Berl.) 23:207-217.

García-March, J. R. \& N. Vicente. 2006. Protocol to study and monitor Pinna nobilis populations within marine protected area. Malta: MedPAN, Malta Environmental and Planning Authority. 79 pp.

García-March, J. R., A. M. García-Carrascosa, A. L. Pena Cantero \& Y. G. Wang. 2007a. Population structure, mortality and growth of Pinna nobilis Linnaeus, 1758 (Mollusca, Bivalvia) at different depths in Moraira bay (Alicante, Western Mediterranean). Mar. Biol. 150:861-871.

García-March, J. R., L. Perez-Rojas \& A. M. García-Carrascosa. 2007b. Influence of hydrodynamic forces on population structure of Pinna nobilis Linnaeus, 1758 (Mollusca: Bivalvia): the critical combination of drag force, water depth, shell size and orientation. J. Exp. Mar. Biol. Ecol. 342:202-212.

Jacoby, D. \& M. Gollock. 2014. Anguilla anguilla. The IUCN red list of threatened species. Version 2014.3. Available at: www.iucnredlist.org.
James, R., J. A. Theodorou \& C. Hellio. 2010. Population study of the endangered bivalve Pinna nobilis (Fan mussel) in the Maliakos Gulf, Greece. In: 5th International Congress on Aquaculture, Fisheries Technology and Environmental Management. November 25-27, 2010, Aquaculture \& Fisheries Department, T.E.I. of Messolongi, Greece.

Katsanevakis, S. 2006. Population ecology of the endangered fan mussel Pinna nobilis in a marine lake. Endanger. Species Res. 1:51-59.

Katsanevakis, S. 2007. Density surface modelling with line transect sampling as a tool for abundance estimation of marine benthic species: the Pinna nobilis example in a marine lake. Mar. Biol. 152:77-85.

Katsanevakis, S. \& M. Thessalou-Legaki. 2009. Spatial distribution, abundance and habitat use of the protected fan mussel Pinna nobilis in Souda Bay, Crete. Aquat. Biol. 8:45-54.

Katsanevakis, S., D. Poursanidis, Y. Issaris, A. Panou, D. Petza, V. Vassilopoulou, I. Chaldaiou \& M. Sini. 2011. "Protected" marine shelled molluscs: thriving in Greek seafood restaurants. Med. Mar. Sci. 12:429-438.

Katsares, V., A. Tsiora, S. Galinou-Mitsoudi \& A. Imsiridou. 2008. Genetic structure of the endangered species Pinna nobilis (Mollusca: Bivalvia) inferred from mtDNA sequences. Biologia. 63:412-417.

Kozul, V., N. Glavic, J. Bolotin \& N. Antolovic. 2013. Growth of the fan mussel Pinna nobilis (Linnaeus, 1758) (Mollusca: Bivalvia) in experimental cages in the South Adriatic Sea. Aquacult. Res. 44:31-40.

Leal-Soto, S., R. Barraza-Guardado, R. Castro-Longoria, J. ChávezVillalba \& F. Hoyos-Cháirez. 2011. Cultivation of Pen Shells: an example with Atrina maura in northwestern Mexico. J. World Aq. Soc. 42:789-800.

Mendo, T., V. Koch \& M. Wolff. 2011. Feasibility of intertidal bottom culture of the penshell Atrina maura in Bahia Magdalena, Baja California Sur, Mexico. Aquaculture 314:252-260.

Najdek, M., M. Blazina, D. Ezgeta-Balic \& M. Peharda. 2013. Diets of fan shells (Pinna nobilis) of different sizes: fatty acid profiling of digestive gland and adductor muscle. Mar. Biol. 160:921-930.

Navedo, J. G., G. Fernández, J. Fonseca \& M. C. Drever. 2014. A potential role of shrimp farms for the conservation of nearctic shorebird populations. Estuaries Coasts. DOI: 10.1007/s12237-014-9851-0.

Peharda, M. \& I. Vilibic. 2008. Modelling the recruitment effect in a small marine protected area: the example of saltwater lakes on the Island of Mljet (Adriatic Sea). Acta Adriat. 49:25-35.

Rabaoui, L., S. Tlig-Zouari, A. Cosentino \& O. K. Ben Hassine. 2008. Distribution and habitat of the fan mussel Pinna nobilis (Mollusca: Bivalvia) along the northern and eastern Tunisian coasts. Cah. Biol. Mar. 49:67-78.

Rabaoui, L., S. Tlig-Zouari, A. Cosentino \& O. K. Ben Hassine. 2009. Associated fauna of the fan shell Pinna nobilis (Mollusca: Bivalvia) in the northern and eastern and eastern Tunisian coasts. Sci. Mar. 73:129-141.

Rabaoui, L., S. Tlig-Zouari, S. Katsanevakis \& O. K. Ben Hassine. 2010. Modeling population density of Pinna nobilis (Bivalvia) on the eastern and southeastern coast of Tunisia. J. Moll. Stud. 76:340-347.

Richardson, C. A., H. Kennedy, C. M. Duarte, D. P. Kennedy \& S. V. Proud. 1999. Age and growth of the fan mussel Pinna nobilis from south-east Spanish Mediterranean seagrass (Posidonia oceanica) meadows. Mar. Biol. 133:205-212.

Richardson, C. A., M. Peharda, H. Kennedy, P. Kennedy \& V. Onofri. 2004. Age, growth rate and season of recruitment of Pinna nobilis (L.) in the Croatian Adriatic determined from $\mathrm{Mg}: \mathrm{Ca}$ and $\mathrm{Sr}: \mathrm{Ca}$ shell profiles. J. Exp. Mar. Biol. Ecol. 299:1-16.

Rodrigues, L. C., J. C. J. M. van den Bergh, F. Massa, J. A. Theodorou, P. Ziveri \& F. Gazeau. 2015. Sensitivity of Mediterranean bivalve mollusc aquaculture to climate change and ocean acidification: results from a producers' survey. J. Shellfish Res. (accepted).

Sievers, M., T. Dempster, I. Fitridge \& M. J. Keough. 2014. Monitoring biofouling communities could reduce impacts to mussel aquaculture by allowing synchronisation of husbandry techniques with peaks in settlement. Biofouling. 30:203-212. 
Siletic, T. \& M. Peharda. 2003. Population study of the fan shell Pinna nobilis L. in Malo and Veliko Jezero of the Mljet National Park (Adriatic Sea). Sci. Mar. 67:91-98.

Soria, G., M. F. Lavin \& R. Cudney-Bueno. 2014. Spat availability of commercial bivalve species recruited on artificial collectors from the northern Gulf of California. Seasonal changes in species composition. Aqua. Res. 1-12. DOI: 10.1111/are.12435.

Tagalis, D. \& J. A. Theodorou. 2013. Distribution of the endangered bivalve mollusc Pinna nobilis, (Linnaeus, 1758) in the shallow littoral ecosystem of the Northern Maliakos Gulf (NE Mediterranean, Greece). Presented in 15th Hellenic Congress of Ichthyologists, Thesaloniki, Greece.

Theodorou, J. A., J. Viaene, P. Sorgeloos \& I. Tzovenis. 2011. Production and marketing trends of the cultured Mediterranean mussel Mytilus galloprovincialis L. 1819, in Greece. J. Shellfish Res. 30:859874.

Theodorou, J. A., I. Tzovenis, C. M. Adams, P. Sorgeloos \& J. Viaene. 2014. Risk factors affecting the profitability of the Mediterranean mussel Mytilus galloprovincialis L. 1819, farming in Greece. J. Shellfish Res. 33:695-708.

Theodorou J.A., Perdikaris C. \& Filippopoulos N.G. 2015a. Evolution Through innovation in aquaculture: the case of the Hellenic mariculture industry (Greece). J. Applied Aquac. 27:160-181.
Theodorou, J. A., R. James, D. Tagalis, I. Tzovenis, C. Hellio \& G. Katselis. 2015b. Density and size structure of the endangered bivalve Pinna nobilis, Linaeus 1758 (fan mussel) in the shallow water zone of Maliakos Gulf, Greece. It. J. Zool. (submitted).

Trigos, S., J. R. García-March, N. Vicente, J. Tena \& J. Torres. 2014. Utilization of muddy detritus as organic matter source by the fan mussel Pinna nobilis. Medit. Mar. Sci. 15:667-674.

Vafidis, D., C. Antoniadou, E. Voultsiadou \& C. Chintiroglou. 2014. Population structure of the protected fan mussel Pinna nobilis in the south Aegean Sea (eastern Mediterranean). J. Mar. Biol. Ass. U.K. 94:787-796.

Vicente, N. \& J. C. Moreteau. 1991. Statut de Pinna nobilis L. En Mediterranee (Mollusque Eulamel libranche). In: C. F. Boudouresque, M. Avon, V. Gravez, editors. Les Espèces Marines à Protéger en Méditerranée. Marseille, Gis Posidonie Publ. pp. 159-168.

Zavodnik, D. 1967. Contribution to the ecology of Pinna nobilis L. (Mollusca: Bivalvia) in the northern Adriatic Sea. Thal. Yug. 3:93-103.

Zavodnik, D., M. Hrs-Brenko \& M. Legac. 1991. Synopsis on the fan shell Pinna nobilis L. in the eastern Adriatic sea. In: C. F. Boudouresque, M. Avon, V. Gravez, editors. Les Espèces Marines à Protéger en Méditerranée. Marseille, Gis Posidonie Publications. pp. $169-178$. 